ISSN: 2614-1280, https://jurnal.stie-aas.ac.id/index.php/IJEBAR

\title{
THE INFLUENCE OF PRODUCT VARIATIONS, PRICES AND SALES PROMOTIONS ON CONSUMER DECISIONS IN BUYING MITSUBISHI CARS IN SURAKARTA
}

\author{
M. Hasan Ma'ruf \\ STIE AAS Surakarta, Indonesia \\ hasan.stie.aas@gmail.com
}

\begin{abstract}
The purpose of this study was to analyze the effect of product variations, prices and sales promotions on consumer decisions in buying Mitsubishi cars in Surakarta both partially and partially. The data analysis techniques used are validity test, reliability test, classic assumption test, multiple linear regression analysis, $t$ test, $F$ test, coefficient of determination $\left(\mathrm{R}^{2}\right)$. The results obtained: 1$)$ The results of the $t$ test obtained product variations have a positive and significant effect on purchasing decisions, the price has a positive and significant effect on purchasing decisions and promotion has a positive and significant effect on purchasing decisions, 2) $\mathrm{F}$ test results obtained Sig. amounting to 0,000 smaller than 0.05 or sig. $=0.000<0.05$, so $\mathrm{H}_{\mathrm{o}}$ is rejected so it can be concluded that product variations, prices and promotions have a significant influence together on purchasing decisions. 3) The results of multiple linear regression analysis obtained equation $\mathrm{Y}=0.840+0.294 \mathrm{X} 1+$ $0.291 \times 2+0.371 \times 34)$ The coefficient of determination of the purchase decision is $68.6 \%$ determined by product variation, price and promotion while the remaining $31.4 \%(100 \%-68.6 \%)$ is influenced by other variables outside the variables studied.
\end{abstract}

Keywords: product variation; price; promotion and consumer decision.

\section{INTRODUCTION}

Technological advances that are increasingly developing provide convenience for humans. The rapid development of technology, making humans as creatures that have unlimited need, hopes that there will always be new technologies that will meet their needs. However, consumers will be selective in consuming an item or service that they want to fulfill their needs. Neither is the need for fulfillment of transportation facilities which at this time are much desired to be fulfilled by every person. The car is one of the results of technological advances in the automotive field. Judging from the size, price and operation, the car is a very practical means of transportation. People use cars to help their activities both work, trade, and various other activities that require transportation.

The growth of car use in the current decade is very fast in accordance with the development of technology in the automotive world, so it is not surprising that competition in car sales takes place very tightly and the price offered is competitive, this is not only limited to the sale of the car but the form, 
acceleration, the accessories, the colors and the technological sophistication that accompany it. The selling prices of cars today are very competitive, even the manufacturers are not limited to producing cars for the upper middle class, but now the manufacturers are starting to produce cars at low prices and can be reached by the middle to lower class. Decisions on competitive pricing will make consumers easier in determining their desire to buy a car.

High car needs make more and more manufacturers vying to produce cars so as to increase competition between producers. In the increasingly fierce competition of car manufacturers like today, where consumers are expected in various alternative choices of products offered, the producers are required to always keep abreast of market developments as a basis for decision making.

Market is an important factor to achieve a successful business activity. The goal of the company can be achieved by mastering the market so it must be known and understood about the concept of marketing, namely a business philosophy that states that customer satisfaction is an economic and social requirement for the survival of the company. The marketing concept teaches that the marketing activities of a company must begin with activities to identify and formulate the desires and needs of consumers.

An understanding of consumer behavior in buying a product will be very beneficial for the company in determining and developing the product to be made. Companies must learn consumer behavior from the intended target market so that the resulting product gets an effective response from consumers. Research on who is in the consumer market, what consumers buy, when they buy, who is involved in buying, why consumers buy and how they buy is a market analysis that is closely related to consumers. Consumers will demand a variety of products so that there will be many choices for consumers to determine the product to be purchased. For consumers, product variations will determine their decision to buy products.

In addition to product variations, consumers will consider prices in determining their desire to buy products. With competitive prices and tend to be cheaper than others it will make consumers easier to decide to buy products. The price set for the car sold must of course meet the right elements, because the exact price is seen from the quality of the product. Quality products are appropriate if the price is too expensive and consumers do not object to paying for the product. Likewise, consumers will be disappointed if they have to pay for low-priced products that are of low quality. That is what is said that prices will make consumers easy to buy products offered to these products.

In marketing car dealers will conduct various promotions through print, electronic and other media. Promotions made by these dealers in hopes of being able to bring consumers to come to buy products offered. Through the promotion of this product, consumers will more easily make a decision to buy a product; from the existing promotion about the product will be explained about the benefits of the product so that consumers become aware of the product to be purchased.

In order to succeed car sales of car dealers in Surakarta, various policies are used to serve consumers, including prices, variations in competitive products compared to others, because they are superior products. Another 
factor is the more intense promotion so that car sales will increase sales.

\section{PROBLEM STATEMENT}

1. Are there significant effects of product variations on consumer decisions in buying Mitsubishi cars in Surakarta?

2. Is there a significant price effect on consumer decisions in buying Mitsubishi cars in Surakarta?

3. Is there a significant influence on promotion of consumer decisions in buying Mitsubishi cars in Surakarta?

4. Are there significant influences of product, price and promotion variations on consumer decisions in buying Mitsubishi cars in Surakarta together?

\section{LITERATURE REVIEW}

1. Consumer Behavior

Entrepreneurs who want to succeed must pay attention and understand the needs of consumers. Consumers have differences in terms of desires, needs, education, employment, and income levels, so their behavior also varies. Consumer behavior is a reaction to needs and desires both instinctively and because of the influence of the surrounding environment. Behavior or behavior arises due to various conditions that affect consumers. This results in consumers looking for alternatives that can provide satisfaction and benefits for him. After determining the best alternative according to him, then consumers begin to consider taking a purchase decision. The understanding of consumer behavior is:
Consumer behavior is individual activities which directly involve to get and use goods and sevice, including the taken decision process on preparation and the determining of those activities (Basu Swastha and T. Hani handoko, 2009 : 10).

Based on the consumer behavior above, it can be conclude that consumer beahvior is an action that done by individual, group, or organization which relate on the process of determining the decision to get, to use the economics goods and services which can be influencd by the enviroment. From these definitions, important elements of consumer behavior can be taken, namely decision-making processes and activities which all involve individuals in assessing, obtaining economic goods and services.

2. Product Purchase Decision

Decision making and behavior that influence it, this is a system. "The system is a totality or a whole which consists of parts that are interconnected, working together to achieve the stated goals" $(\mathrm{H}$. Buchari Alma, 2007: 102). Buying decisions can be interpreted as follows;

Purchasing decision making is a decision to buy someone whose origin is influenced by the environment, culture, family and so on, will form an attitude on the individual, then make a purchase (Buchari Alma, 2007: 102).

As for the stages in the buying decision making process, as follows:
a. Need recognition
b. Information search
c. Evaluation of alternatives
d. Purchase decision 
e. Postpurchase behavior (Buchari Alma, 2007: 104-105).

Decision making by consumers to purchase a product begins with an awareness of needs. Furthermore, if you have realized the needs and desires, then the consumers will find information about the existence of the product they want. This information search process will be carried out by gathering all information related to the desired product. From various information obtained by consumers, the selection of alternatives is available. This selection process is called the information evaluation stage. By using various criteria that exist in the minds of consumers, one product brand is chosen to be purchased (Sutisna, 2010: 15).

With the purchase of certain product brands, the evaluation process has not ended because consumers will conduct a post purchase evaluation. This process will determine whether consumers feel satisfied or not for their purchase decisions. If the consumer feels satisfied, then the possibility to buy back in the future will occur, while the consumer is not satisfied with the purchase decision, he will look for the product information he needs, he will look for the product information he needs. The process will continue until the consumer feels satisfied with the decision to purchase the product (Sutisna, 2010: 16).

\section{HYPOTHESIS}

1. Product variations have a significant effect on consumer decisions in buying Mitsubishi cars in Surakarta.
2. Prices have a significant effect on consumer decisions in buying Mitsubishi cars in Surakarta.

3. Promotion has a significant effect on consumer decisions in buying Mitsubishi cars in Surakarta.

4. Product variations, prices and promotions have a significant effect on consumer decisions in buying Mitsubishi cars in Surakarta together.

\section{RESEARCH METHODS}

1. The scope of research This type of research is quantitative research with survey methods. Therefore this research was conducted with a survey in Surakarta.

2. Data Source

a. Primary Data

Primary data is data collected and obtained directly by researchers in the field by conducting a survey conducted using a questionnaire (questionnaire).

b. Secondary Data

Secondary data is data obtained indirectly by researchers. This secondary data is for example searched through documentation data that has been recorded by the company under study, books, magazines, information or other publications. Secondary data used in this research is theory theories taken from supporting books.

3. Operational Definition Variables examined

a. Product variation

Product variations are various types of products offered to be selected and 
ISSN: 2614-1280, https://jurnal.stie-aas.ac.id/index.php/IJEBAR

purchased by consumers. Product variation indicators are the ease of getting products, completeness of products and the desire to buy. Measurement scale is using a Likert scale. Variable product variations consist of five question items.

b. Price

Price is the amount of money given to get a desired motorcycle. The indicators are affordable, standard, relative, varied, and stable. Measurement is scale using a Likert scale. The price questionnaire consists of five question items.

c. Promotion

Promotion is a marketing activity undertaken by a company to increase sales. Indicators are advertising, personal selling, payment systems, and discounted prices. Measurement scale is using a Likert scale. Promotional variables consist of five question items.

d. Consumer's decision to buy a car The consumer's decision to buy a car is a concrete action taken by consumers to make a decision to purchase a car. The indicators are environmental factors (friends and neighbors), on their own desires, products, family influences, and advertisements. Measurement scale is using scala likert. Consumer decisions in buying a car questionnaire question consists of five question items.

4. Population and Sample

a. Population

The population consists of a set of objects that are the center of information that wants to be contained (W. Gulo, 2012: 76). In this study the population is consumers of PT. SUN Motor Solo in September 2014.

b. Sample

The sample is a subset of a population (W. Gulo, 2012: 78) The sample used in this study is all members of the population due to population limitations so that all are used as samples or total samples. This sampling technique is also called a census (Suharsimi Arikunto, 2012: 134).

5. Data Type

a. Qualitative data are research data in the form of responses, opinions, attitudes or characteristics of a person or group of people who are respondents. The results of the respondent's data are then converted into quantitative data using a Likert scale.

b. Quantitative data is data that can be measured by a numeric scale (numbers).

6. Data Collection Procedure

a. Questionnaire

Data collection is done by questionnaire. Questionnaires or questionnaires are a way of collecting data by providing a list of questions that have been prepared previously by the researcher in accordance with the indicators in the variables studied. This questionnaire is used to obtain data to be analyzed against the variables studied.

b. Observation 
Observation is a way of collecting data by making direct observations of the space to complete the data obtained.

c. Documentation

Documentation is a method of collecting data by copying data recorded by certain parties. This documentation data is used to support the completeness of the data in the study.

7. Data analysis technique

a. Instrument Test

1) Validity Test Validity test is a measure that shows the level of validity or validity of an instrument. Valid or valid instruments have high validity, whereas instruments that are less valid or valid have low validity. (Suharsimi Arikunto, 2012: 160). An instrument is said to be valid if it is able to measure what is desired. An instrument is said to be valid if it can reveal data from the variables that are examined appropriately. Valid criteria are a question if the $r_{x y}$ value is greater than the $r_{\text {table }}$ value (Suharsimi Arikunto, 2012: 70), where the $r_{\text {tabel }}$ value is at a significant level or $\alpha=0.05$.

2) Reliability test

According to Suharsimi Arikunto (2012: 162) stated "the test is said to be reliable if it gives a fixed result when pressed repeatedly". To test the reliability using Alpha Cronbach technique (Suharsimi Arikunto, 2012: 192).

3) Classic assumption test a) Multicollinearity Test

Multicollinearity is a perfect or definite linear relationship between several or all independent variables of the regression model.

Multicollinearity test aims to test whether the regression model determined the correlation between independent variables. The rules used to detect the presence or absence of multicollinearity can be seen from the value of the tolerance value and variance inflation factor (VIF), if the tolerance value is less than 0.10 or the VIF value below 10 means multicollinearity (Ghozali Imam, 2010: 87).

b) Normality test

The normality test aims to test whether the dependent variable and independent variables have normal distribution or not. Normality Test uses the Kolmogorov - Smirnov test, with this test can be known that the data used is normally distributed or not. If according to the criteria: Asym Sig (2tailed)> significant criteria ( $p$ value) 0.05 , then the data is normally distributed from the opposite.

c) Heterocedacity test

Heterocedacity test aims to test whether in the regression model there is residual 
ISSN: 2614-1280, https://jurnal.stie-aas.ac.id/index.php/IJEBAR

variance uncertainty one observation to another observation. The method that can be used to test for this symptom is Glejser, for absolute residuals, then, it regresses the absolute residual value obtained as the dependent variable and regresses from the independent variables. The $t_{\text {count }}$ of residual absolute lies between $\mathrm{t}$ table and df (n-1-k) with a significant level of 0.05 , heteroscedasticity occurs (Ghosali Imam, 2010: 117).

4) Hypothesis testing

a) Multiple Linear Regression Analysis

This multiple linear regression analysis is used to determine the effect of independent variables, namely product variation, price and promotion on the dependent variable of the decision of the consumer in buying a car, with the formula:

$\mathrm{Y}=\mathrm{a}+\mathrm{b} 1 \mathrm{X} 1+\mathrm{b} 2 \mathrm{X} 2+\mathrm{b} 3 \mathrm{X} 3$

+ e (Djarwanto PS, 2009:309)

Whereas :

$\mathrm{Y}=$ Consumer's decision to buy a car a $=$ Constant value $\mathrm{b} 1, \mathrm{~b} 2, \mathrm{~b} 3=$ Regression coefficient X1X2X3

$\mathrm{X} 1=$ Product variation

$\mathrm{X} 2=$ Price $\mathrm{X} 3=$ Promotion $\mathrm{e}$

$=$ Error

b) t test
This test is to test the level of significance of the influence of each or partially independent variables (variations in product, price and promotion) of the dependent variable (the consumer's decision to buy a car).

c) F test

The $\mathrm{F}$ test is used to determine the effect of independent variables (product variations, prices and promotions) on the dependent variable (consumer's decision to buy a car) together.

d) Determination Coefficient Test $\left(\mathrm{R}^{2}\right)$

The coefficient of determination is to determine the degree of influence in the form of percentage of independent variables (product variations, prices and promotions) to the dependent variable (the decision of consumers in buying a car), used the determination analysis formula (R2).

\section{RESEARCH RESULTS}

The effect of purchasing decisions on product variation variables has a significant effect. This means that any additional product variations made by the company will increase consumer purchasing decisions. The variety of products will make buyers easier to determine the choice of products to be purchased. Product variations provided by the company include the ease of getting products that vary from company to various choices of product 
variations, the company provides a variety of products and there is a desire to buy from consumers because of the variety of products available.

Price variable influences purchasing decisions. Consumers in buying price products are a priority to determine product purchases, prices also become the basis of consumers to know the comparison of product quality and the value of the benefits provided. The price given by the company to attract consumers decides to buy is at affordable prices, standard prices, relative prices, vary in determining the price of the product, and prices are made stable fluctuations in the exchange rate of the system increases the price does not follow dollar fluctuations in the market.

Consumers understand the product because of the promotion made by the company. In this study promotion has a significant effect on purchasing decisions, it means that the better the promotion and the more attractive promotions it will make consumers more easily decide on product purchases. Promotions by companies include advertising by making advertisements in various media both electronic, mass media and so on, promotions through personal selling are also still chosen by companies because car sales will be effective if supported by salespeople because they can be more specific in explaining product details to customers, systems payment, and price discounts.

\section{CONLUSION}

1. The F test results are known as the Sig. equal to 0,000 less than 0.05 or sig. $=0,000<0,05$, so $\mathrm{H}_{\mathrm{o}}$ is rejected so it can be concluded that product variations, prices and promotions have a significant effect together on purchasing decisions.

2. Variable product variation (X1) has a positive and significant effect on purchasing decision variables (Y). Hypothesis 2 is proven to be true.

3. Price variable $\left(\mathrm{X}_{2}\right)$ has a positive and not significant effect on the purchasing decision variable (Y). Hypothesis 3 is proven to be true.

4. Promotion variable $\left(\mathrm{X}_{3}\right)$ has a positive and significant effect on the purchasing decision variable (Y). Hypothesis 4 is proven to be true.

5. The coefficient of determination $\left(\mathrm{R}^{2}\right)$ is known that the purchase decision is $68.6 \%$ determined by product variation, price and promotion while the remaining $31.4 \%$ $(100 \%-68.6 \%)$ is influenced by other variables outside the variables studied.

\section{SUGGESTION}

1. Companies need to add more variety of products that consumers have more opportunities to make choices when buying. Product variations that can be made of its type, color and so on.

2. In order to pay attention to the price of purchasing decisions, the price of the right factor is that the price of the right factor is that the consumers feel interested in making a purchase.

3. Promotions from the results show a significant and also dominant influence on purchasing decisions, for that dealers should maintain the promotion that has been increased so that sales increase. 
International Journal of Economics, Business and Accounting Research (IJEBAR)

Peer Reviewed - International Journal

Vol-1, Issue-1, 2017 (IJEBAR)

ISSN: 2614-1280, https://jurnal.stie-aas.ac.id/index.php/IJEBAR

\section{REFERENCES}

Afif Ardadina, 2010, Analisis Pengaruh Harga, Produk dan Promosi terhadap Keputusan Pembelian Yamaha MIO di Sukoharjo (Survei pada Dealer Tunas Jaya Motor Bekonang), Tidak dipublikasikan FE UNISRI, Surakarta.

Basu Swastha DH, 2010, Asas-asas Marketing, Liberty, Yogyakarta.

Basu Swastha DH dan T. Hani Handoko, 2009, Manajemen Pemasaran: Analisa Perilaku Konsumen, Liberty, Yogyakarta.

Buchari Alma, 2007, Manajemen Pemasaran dan Pemasaran Jasa, Alfabeta, Bandung.

Dewi Rasmiati, 2010, Analisis Pengaruh Kualitas Produk, Harga dan Promosi terhadap Keputusan Konsumen dalam Membeli Produk pada Koperasi Pegawai Negeri "Sidomulyo" di Sambi Boyolali, Tidak dipublikasikan FE UNISRI, Surakarta.

Djarwanto PS \& Pangestu Subagyo, 2005, Statistik Induktif, Edisi 4, BPFE UGM, Yogyakarta.

Djarwanto Ps \& Pangestu Subagyo, 2009, Statistik Induktif, Edisi 5, BPFE UGM, Yogyakarta.
Hani Handoko. T, 2009, Manajemen Personalia dan Sumber Daya Manusia, BPFE-UGM, Yogyakarta.

Hendra Nugraha, 2008, Pengaruh Produk, Harga dan Saluran Distribusi terhadap Keputusan Membeli Minyak Goreng merek camar 18 Liter di Toko Enggal Dadi Surakarta, Tidak dipublikasikan FE UNISRI, Surakarta.

Imam Ghozali, 2010, Aplikasi Analisis Multivariate dengan Program SPSS, Badan Penerbit UNDIP, Semarang.

Kotler, Philip dan Gary Armstrong, 2009, Dasar-dasar Pemasaran, Alih Bahasa Alexander Sindoro, Prenhallindo, Jakarta.

Suharsimi Arikunto, 2002, Manajemen Penelitian, Rineka Cipta, Jakarta. Suharsimi Arikunto, 2012, Prosedur Penelitian Suatu Pendekatan Praktik, Rineka Cipta, Jakarta.

Sutisna, 2010, Perilaku Konsumen dan Komunikasi Pemasaran, PT. Remaja Rosdakarya, Bandung.

Sutrisno Hadi, 2010, Statistik Terapan, Liberty, Yogyakarta. W. Gulo, 2012, Metodologi Penelitian, PT. Grasindo, Jakarta. 